ORIGINAL ARTICLE

\title{
Biomass and radiation use efficiency in Eucalyptus plantations as affected by spacing of planting
}

\author{
Eficiência no uso de biomassa e radiação de plantações de eucalipto afetadas \\ pelo espaçamento de plantio
}

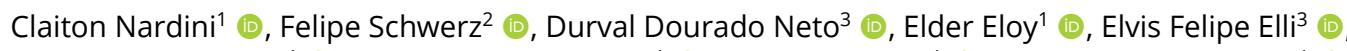
Jaqueline Sgarbossa ${ }^{4}$ (D), Liliane Bárbara Tibolla ${ }^{1}$ (D), Denise Schmidt ${ }^{1}$ (i), Braulio Otomar Caron ${ }^{1}$ (1)

${ }^{1}$ Universidade Federal de Santa Maria - UFSM, Frederico Westphalen, RS, Brasil

${ }^{2}$ Universidade Federal de Lavras, Lavras, MG, Brasil

${ }^{3}$ Escola Superior de Agricultura "Luiz de Queiroz" - ESALQ, Universidade de São Paulo - USP, Piracicaba, SP, Brasi
\end{abstract}

${ }^{4}$ Universidade Federal de Santa Maria - UFSM, Santa Maria, RS, Brasil

How to cite: Nardini, C., Schwerz, F., Dourado Neto, D., Eloy, E., Elli, E. F., Sgarbossa, J., Tibolla, L. B., Schmidt, D., \& Caron, B. O. (2020). Biomass and radiation use efficiency in Eucalyptus plantations as affected by spacing of planting. Scientia Forestalis, 48(128), e3413. https://doi.org/10.18671/scifor.v48n128.19

\begin{abstract}
Spacing of planting is one of the most important silvicultural decisions to be made during implementation of forest stands. The objective of this study was to evaluate the influence of spacing of planted trees on biomass production and solar radiation use efficiency in a Eucalyptus forest plantation in southern Brazil. A field experiment was conducted from September 2008 to September 2017 in the city of Frederico Westphalen, State of Rio Grande do Sul, Brazil. In this study, we evaluated the influence of the spacing of trees on solar radiation use efficiency, interception of solar radiation, leaf area index, biomass yield, and partitioning in the Eucalyptus forest plantation. The conversion efficiency of the photosynthetically active radiation intercepted in the biomass was manipulated by changing the spacing of the trees, and the highest conversion efficiency was $0.0062 \mathrm{~kg} \mathrm{MJ}^{-1}$ for the $2.0 \times 1.5 \mathrm{~m}$ planting spacing. Eucalyptus trees grown on the $2.0 \times 1.0 \mathrm{~m}$ planting spacing showed the highest biomass yield with $961.4 \mathrm{Mg} \mathrm{ha} \mathrm{g}^{-1}$, showing that the most efficient plants in the conversion of photosynthetically active radiation are not always the most productive. As a result, the hypothesis of this study was confirmed. Forest managers can accelerate growth and increase the production of forest biomass by adequately manipulating the spacing between the trees.
\end{abstract}

Keywords: Biomass partitioning; Forest plantations; Leaf area index; Solar radiation interception; Extinction coefficient.

\section{Resumo}

O espaçamento de plantios é uma das mais importantes decisões silviculturais a serem definidas durante a implementação de povoamentos florestais. O objetivo deste trabalho foi avaliar a influência do espaçamento de plantios na produção de biomassa e a eficiência do uso de radiação em um plantio florestal de eucalipto no sul do Brasil. Um experimento de campo foi conduzido de setembro de 2008 a setembro de 2017 na cidade de Frederico Westphalen, RS, Brasil. Para atingir o objetivo do estudo, avaliou-se eficiência no uso da radiação solar, interceptação da radiação solar, índice de área foliar, rendimento de biomassa e partição. A eficiência de conversão da radiação fotossinteticamente ativa interceptada na biomassa foi afetada pelo espaçamento de plantio e a maior eficiência de conversão foi de $0,0062 \mathrm{~kg} \mathrm{MJ}^{-1}$ para o espaçamento de 2,0 × 1,5 m. Além disso, as árvores de eucalipto cultivadas no espaçamento de $2,0 \times 1,0 \mathrm{~m}$ apresentaram o maior rendimento de biomassa com 961,4 $\mathrm{Mg} \mathrm{ha}^{-1}$, demonstrando que nem sempre as plantas mais eficientes na conversão de radiação fotossinteticamente ativa são as mais produtivas. Portanto, a hipótese deste estudo foi confirmada, uma vez que os

Financial support: None.

Conflict of interest: Nothing to declare.

Corresponding author: claitonnardini@live.com

Received: 21 June 2019.

Accepted: 23 October 2019.

Editor: Paulo Henrique Müller Silva. (c) This is an Open Access article distributed under the terms of the Creative Commons Attribution License, which permits unrestricted use,
distribution, and reproduction in any medium, provided the original work is properly cited. 
produtores florestais podem acelerar o crescimento e aumentar a produção de biomassa florestal, utilizando espaçamento de plantio adequado.

Palavras-chave: Partição de biomassa; Plantios florestais; Índice de área foliar; Interceptação de radiação solar; Coeficiente de extinção.

\section{INTRODUCTION}

There is an increased demand for forest biomass as an alternative energy source because trees have the capacity to retain and store greenhouse gases and reduce the emission of pollutants from fossil sources (Sanquetta et al., 2014a; Sereghetti et al., 2015). Forest plantations are considered to be economically viable to meet societal energy demands, gaining increasing importance in the Brazil energy matrix (Silva et al., 2015).

The increasing demand for biomass has increased the number of short-rotation forest plantations, especially those belonging to the genus Eucalyptus. This genus is widely used in forestry due to its features such as good adaptability in different environments, and its high productivity and accelerated growth rate. Plant breeding programs have sought more efficient and productive forest plantations, aiming for rapid biomass accumulation per hectare to be used for energy production (Lopes et al., 2017). Brazil has extensive biomass resources that could potentially meet the country's total primary energy demand, as well as aid in becoming a major exporter of energy resources (Welfle, 2017).

In this context, plant spacing is one of the major factors that foresters consider in the implementation of new forest energy plantations. The most commonly used spacing is the one which provides a useful area per plant varying from 3 to $9 \mathrm{~m}^{2}$ (Gonçalves et al., 2013). According to Sereghetti et al. (2015), plant spacing affects the final production, as it determines plant density, trunk size, and quality (Pinkard \& Neilsen, 2003). The spacing defines the amount of resources available for individual tree growth. Under reduced plant spacing, the incident solar radiation can be a limiting factor for plant growth and development, and thus may affect forest biomass production.

The conversion of the intercepted photosynthetically active radiation into biomass is based on the solar radiation use efficiency (RUE) of the plant (Monteith, 1977). The RUE is affected by the leaf area index, which may change according to plant density, and also in response to biotic and abiotic factors (Sanquetta et al. 2014b; Binkley et al., 2010; Gonçalves et al., 2013; Stape et al., 2004). According Pretzsch \& Biber (2016), little attention has been given to RUE and how it can improve forest yields. Recently, however, there has been increasing interest in using ecological information, such as photosynthesis-light relationships in trees in order to improve yield.

More studies that are aimed to meet the global energy demand to mitigate negative effects of climate change are needed. In this context, this study proposes to increase forest productivity by improving the RUE of forest systems. We propose to evaluate the feasibility of the use of reduced planting spacings in order to enhance radiation use efficiency, as well as to assess forest biomass yield and partitioning, which are important traits when the aim is to produce forest biomass for energy generation.

Given the lack of studies on the effect of plant spacing on radiation use efficiency and biomass yield and partitioning in forest energy plantations, the following hypotheses were proposed: (i) planting spacing affects radiation use efficiency, as the reduced plant spacing improves the interception of solar radiation; and (ii) reduced plant spacing provides greater biomass yield per unit area when compared to the traditional planting spacing used by forest producers $(3.0 \times 1.5 \mathrm{~m})$. In order to test the hypotheses, we evaluated the influence of plant spacing on the accumulated biomass and solar radiation use efficiency in Eucalyptus plantations in Southern Brazil. 


\section{MATERIAL AND METHODS}

\section{Study area and experimental design}

A field study was conducted from September 2008 to September 2017 in the experimental area of the Laboratory of Plant Biometry and Laboratory of Agroclimatology of the Federal University of Santa Maria campus of Frederico Westphalen, State of Rio Grande do Sul, Brazil, located at coordinates $27^{\circ} 22^{\prime} \mathrm{S}, 53^{\circ} 25^{\prime} \mathrm{W}$ with an altitude of $480 \mathrm{~m}$. According to the Köppen climate classification, the climate is Cfa, i.e., humid subtropical with occurrence of rainfall in all months of the year and a mean annual temperature of $19.1{ }^{\circ} \mathrm{C}$, and varying maximum and minimum temperatures of $38^{\circ} \mathrm{C}$ and $0{ }^{\circ} \mathrm{C}$, respectively (Alvares et al., 2013). The soil of the experimental area is typical Oxisol, with clayey texture, and is deep and welldrained. Fertilization was carried out during planting, where $150 \mathrm{~g}$ of fertilizer was applied to each seedling. Planting of Eucalyptus seedlings (Eucalyptus grandis) was manually carried out in September 2008, after soil plowing and harrowing. The experimental design was a randomized complete block, characterized by af actorial scheme of $5 \times 4$, with five assessment periods after planting (1st, 3rd, 5th, 7thand 9th year) and four spacings between plants $(2.0 \times$ $1.0 \mathrm{~m} ; 2.0 \times 1.5 \mathrm{~m} ; 3.0 \times 1.0 \mathrm{~m}$, and $3.0 \times 1.5 \mathrm{~m})$, with three replications each. A sketch of an experimental unit can be seen in Schwerz et al. (2019), who used the same experimental design for black wattle plantations.

\section{Forest biomass evaluation, mean annual increment and current annual increment}

Destructive tree assessments were performed in the month of September in five assessment years: 1st year (2009), 3rd year (2011), 5th year (2013), 7th year (2015), and 9th year (2017) after planting. For each spacing of planting, nine trees were evaluated, resulting in a total of 36 trees per assessment year, totaling 180 trees evaluated during the rotation. The forest biomass of each tree compartment (trunk, bark, branches, and leaves) was evaluated through the direct method, which consists of cutting and weighing the different tree compartments (Sanquetta, 2002). The leaf and branch samples were collected in the lower, middle and upper canopy strata of the trees in order to obtain a homogeneous material that represents the whole canopy. The samples were identified and then taken to a drying oven to obtain the dry biomass. Samples of trunk, bark, leaf, and branch were dried at $103^{\circ} \mathrm{C}$ to obtain $0 \%$ moisture, allowing for subsequent determination of the respective moisture content.

The total biomass was determined by adding the dry biomass of the different tree compartments (bole $=$ trunk + bark and canopy $=$ leaves + branches). To quantify the biomass produced per hectare, the following survival rates were recorded: 1 st year (2009) and 3rd year (2011): 100\%, 5th year (2013): 94\%, 7th year (2015): 89\% and in the 9th year (2017); with 61\%, $62 \%, 54 \%$, and $72 \%$ for spacings $2.0 \times 1.0 \mathrm{~m} ; 2.0 \times 1.5 \mathrm{~m} ; 3.0 \times 1.0 \mathrm{~m}$, and $3.0 \times 1.5 \mathrm{~m}$, respectively.

With biomass data, the current annual increment (CAI) and the mean annual increment (MAI) of Eucalyptus were calculated. To calculate CAI, the following equations were used:

$$
C A I_{X}=X_{I+1}-X_{I}
$$

where: $\mathrm{CAl}_{\mathrm{X}}=$ current annual increment $\left(\mathrm{Mg} \mathrm{ha}^{-1}\right) ; \mathrm{X}_{I+1}=$ biomass obtained at age $\mathrm{I}+1 ; \mathrm{X}_{I}=$ biomass obtained at age I. To determine the MAl, we used the following equation:

$$
M A I_{X}=\frac{X_{I}}{I}
$$

where: $\mathrm{MAI}_{\mathrm{X}}=$ mean annual increment $\left(\mathrm{Mg} \mathrm{ha}^{-1}\right) ; \mathrm{X}_{\mathrm{I}}=$ biomass obtained at age I (years). 


\section{Solar radiation interception, weather data and radiation use efficiency}

The values for solar radiation interception were measured annually, where the solar radiation intercepted was measured above and under the tree arrangement using a portable sensor pyranometer (LICOR PY32164) coupled to a Datalogger (LICOR 1400). The measurements were recorded from 10 to $12 \mathrm{~h}$. Sample points within each plot were systematically established in three different directions: one located within the row (1), another between each row (2), and the third at a $45^{\circ}$ angle between points 1 and 2 (Behling et al., 2015). The values of solar radiation interception were obtained using the following equation:

$\%$ Intercepted $=[100-(R n \times 100 / R t)]$

where $\mathrm{Rn}=$ incident radiation under the canopy; $(\mathrm{Rt}=$ incident radiation above the canopy.

Data of incident solar radiation $\left(\mathrm{MJ} \mathrm{m} \mathrm{m}^{-2}\right)$, rainfall $\left(\mathrm{mm} \mathrm{dia}^{-1}\right)$ and air temperature (minimum, average and maximum $\left({ }^{\circ} \mathrm{C}\right)$ ), were collected from a weather station belonging to the Brazilian National Institute of Meteorology (INMET), located approximately $500 \mathrm{~m}$ from the experimental area. The value of photosynthetically active radiation was considered to be $45 \%$ of global solar radiation, the average value found by Assis \& Mendez (1989).

The monthly and annual accumulated solar radiation, rainfall, and minimum, average, and maximum air temperatures obtained during the experiment (September 2008 to September 2017) are shown in Figure 1. Air temperature varied from $-2.7^{\circ} \mathrm{C}$ (minimum) to $37^{\circ}$ $\mathrm{C}$ (maximum) with a mean annual rainfall of $2109.04 \mathrm{~mm}$.

In order to evaluate the RUE, the leaf area of the trees was quantified using three samples of 300 grams of different canopy strata (Sanquetta, 2002). Leaf area was obtained using the leaf area integrator, model LI-3000C. Samples were placed in individual paper bags, identified and placed in an air circulation oven at $60{ }^{\circ} \mathrm{C}$ until reaching constant mass. Samples were weighed on a precision scale to obtain the leaf biomass. Thus, the leaf area was calculated by the following equation:

$L A=\left(L B^{*} L s\right) / D B s$

where: $L A=$ leaf area $\left(\mathrm{m}^{2}\right) ; \mathrm{LB}=$ leaf biomass $(\mathrm{kg}) ; \mathrm{Ls}=$ sample leaf area $\left(\mathrm{m}^{2}\right) ; \mathrm{DB}=$ dry weight (kg).

Leaf area index (LAI) was obtained from the relationship of the total leaf area of each plant and the area of the soil occupied by the plants, as a function of the planting spacing, according the following equation:

$L A I=\frac{L A}{U S A}$

where: $L A I=$ leaf area index; $L A=$ leaf area $\left(\mathrm{m}^{2}\right)$; USA = useful soil area used by the tree $\left(\mathrm{m}^{2}\right)$.

The light extinction coefficient $(k)$ was calculated by the approach from Beer's Law using the following equation proposed by Monsi and Saeki (1953):

$k=-\ln \left(\frac{I}{I_{0}}\right) / L A I$

where: $\mathrm{k}$ = light extinction coefficient; $\mathrm{I}=$ incident solar radiation under the canopy; $\mathrm{I}_{0}=$ incident solar radiation above the canopy; LAI = leaf area index. 

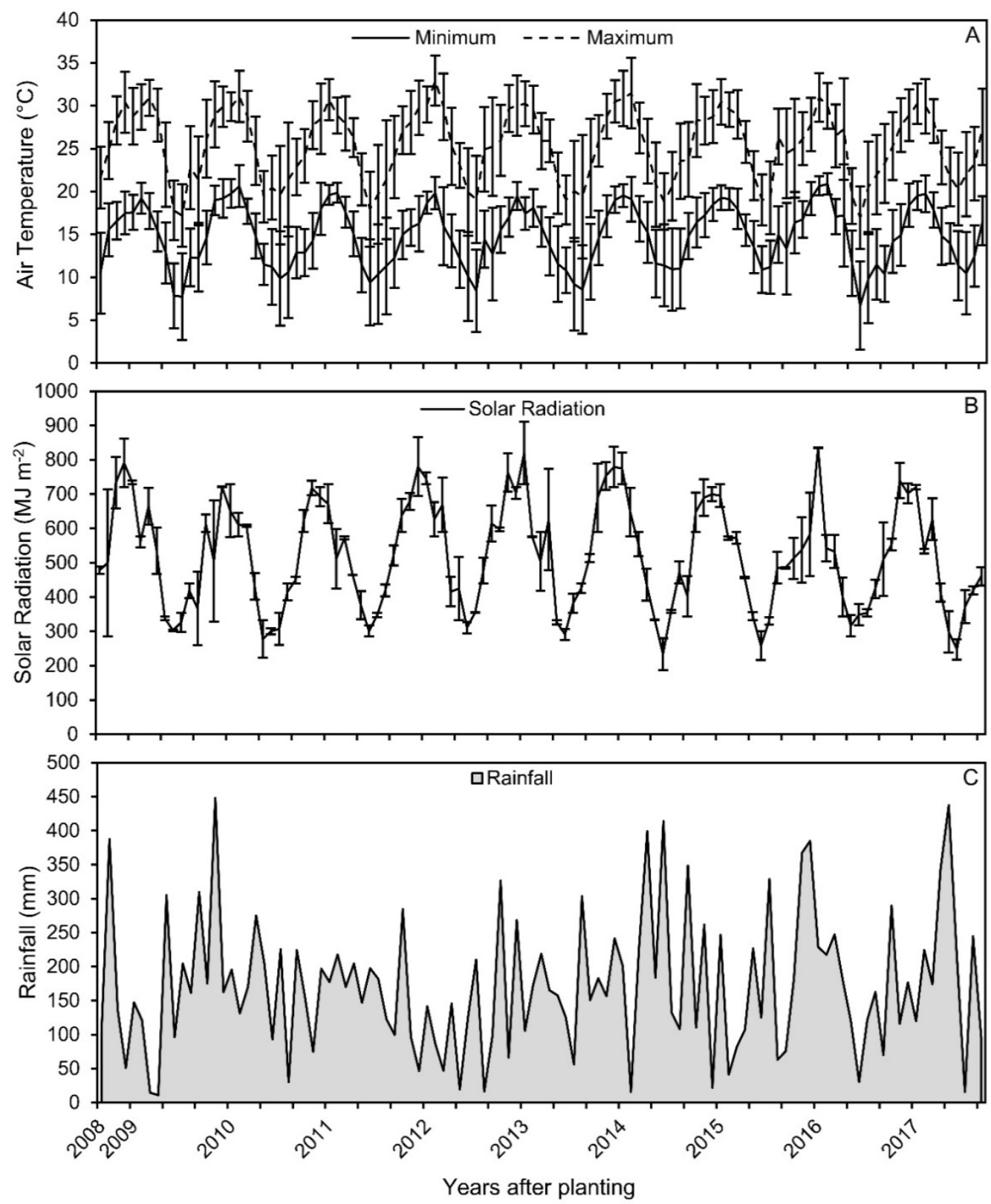

Figure 1- Monthly average values of minimum and maximum air temperature $(A)$, accumulated incident solar radiation (B), and accumulated rainfall (C), during the short-rotation cycle (September 2008 to September 2017).

Values of photosynthetically active radiation intercepted were determined from the model proposed by Varlet-Grancher et al. (1989), according to the following equation:

PARi $=0.95 *($ PARinc $) *\left(\ln ^{\left(-k^{*} L A I\right)}\right)$

where: $\mathrm{PARi}=$ photosynthetically active radiation intercepted $\left(\mathrm{MJ} \mathrm{m}^{-2}\right)$; PARinc $=$ incident photosynthetically active radiation $\left(\mathrm{MJ} \mathrm{m}^{-2}\right) ; \mathrm{k}=$ light extinction coefficient, calculated for each planting spacing.

Radiation use efficiency was determined by the average accumulated biomass production and the intercepted photosynthetically active radiation, based on the model proposed by Monteith (1977): 
where: TDB = total dry biomass produced $\left(\mathrm{kg} \mathrm{m}^{-2}\right) ; \mathrm{PARi}=$ photosynthetically active radiation intercepted $\left(\mathrm{MJ} \mathrm{\textrm {m } ^ { - 2 }}\right)$; $\varepsilon b=$ conversion of photosynthetically active radiation intercepted in biomass produced $\left(\mathrm{kg} \mathrm{MJ}^{-1}\right)$.

The radiation use efficiency given by the linear regression coefficient of the PARi and TDB represents the amount of biomass accumulated for each unit of energy intercepted. The values of $\varepsilon b$ were calculated in terms of total biomass and each compartment (bole and canopy).

\section{Statistical analysis}

The data were analyzed with the software Statistical Analysis System (2003), where analysis of variance, F test and Tukey test $(p<0.05)$ were performed. The Bartlett test was used to verify the homogeneity of variances, while the normality distribution of all data was checked using Shapiro-Wilk test. We rejected the null hypothesis $\mathrm{HO}$.

\section{RESULTS AND DISCUSSION}

\section{Radiation use efficiency of Eucalyptus plantations}

RUE was influenced by the spacing of planting (Figure 2). The highest $\varepsilon b\left(0.0062 \mathrm{~kg} \mathrm{MJ}^{-1}\right)$ was found for the spacing of $2.0 \times 1.5 \mathrm{~m}$. The trunk (trunk + bark) presented $\varepsilon b$ of $0.0048 \mathrm{~kg}$ $\mathrm{MJ}^{-1}$ and the canopy (branches + leaves) presented a $\varepsilon b$ of $0.0009 \mathrm{~kg} \mathrm{MJ}^{-1}$. The values found in this study are higher than those found by other authors. Landsberg \& Hingston (1996), analyzing the $\varepsilon b$ of Eucalyptus globulus in Western Australia and found average $\varepsilon b$ values of 0.00093-0.00223 kg MJ ${ }^{-1}$; Campoe et al. (2013a) found $\varepsilon b$ values from 0.00075 to $0.00103 \mathrm{~kg}$ $\mathrm{MJ}^{-1}$ for dominant and non-dominant trees of Eucalyptus grandis in Brazil, respectively; Le Maire et al. (2013), studying Eucalyptus grandis and Acacia mangium plantations in southern Brazil, found average values of 0.00105 and $0.00087 \mathrm{~kg} \mathrm{MJ}^{-1}$, respectively; Forrester et al. (2013) found values of $\varepsilon b$ varying from 0.00084 to $0.00114 \mathrm{~kg} \mathrm{MJ}^{-1}$. We believe the divergence in RUE values between the literature and those found in the present study can be related to different site characteristics, species and age of plants, and stand management practices.

We observed that the trunk was responsible for $86 \%$ and the canopy $14 \%$ of the total RUE of the tree compartments. In forest plantations for energy production, the most important yield is trunk biomass. However, the canopy is of essential importance as the tree needs to intercept a large amount of radiation in order to meet its energy demand. In this context, the evaluation of RUE that takes into account the total biomass of trunk and canopy appears to be appropriate, by considering these compartments; it simplifies the most important responses, which was confirmed in this study.

Studies that evaluate the influence of spacing of trees on the RUE of different species are in agreement with the results found in the present study. Caron et al. (2012), Sanquetta et al. (2014b), Schwerz et al. (2017), and Schwerz et al. (2019), reported that plants grown under high densities are more efficient in converting solar radiation into biomass. This variation may be related with the ability to efficiently use the available resources, as well as the values of LAI and intercepted solar radiation, parameters that are essential to determine the RUE.

The RUE observed for the spacing of planting of $2.0 \times 1.5 \mathrm{~m}$ was $8 \%, 14.5 \%$, and $16.1 \%$ higher than the planting spacings $2.0 \times 1.0,3.0 \times 1.0$, and $3.0 \times 1.5 \mathrm{~m}$, respectively. This result may be related to the greater amount of radiation intercepted by the tree canopy, which resulted in a higher photosynthetic rate, and consequently greater RUE in forest biomass. Moreover, the higher RUE may be explained by the ability of a tree to acquire resources. One of the main factors related to RUE and productivity of forest plantations with high plant densities is related to the uniformity of the plants within the area. Due to the large number of trees competing for space and resources, it is possible to have dominant and non-dominant plants within the 
forest stand (Stape et al., 2010). In general, the Eucalyptus tree grown in the $2.0 \times 1.5 \mathrm{~m}$ spacing showed more stand uniformity than under other tree spacing.
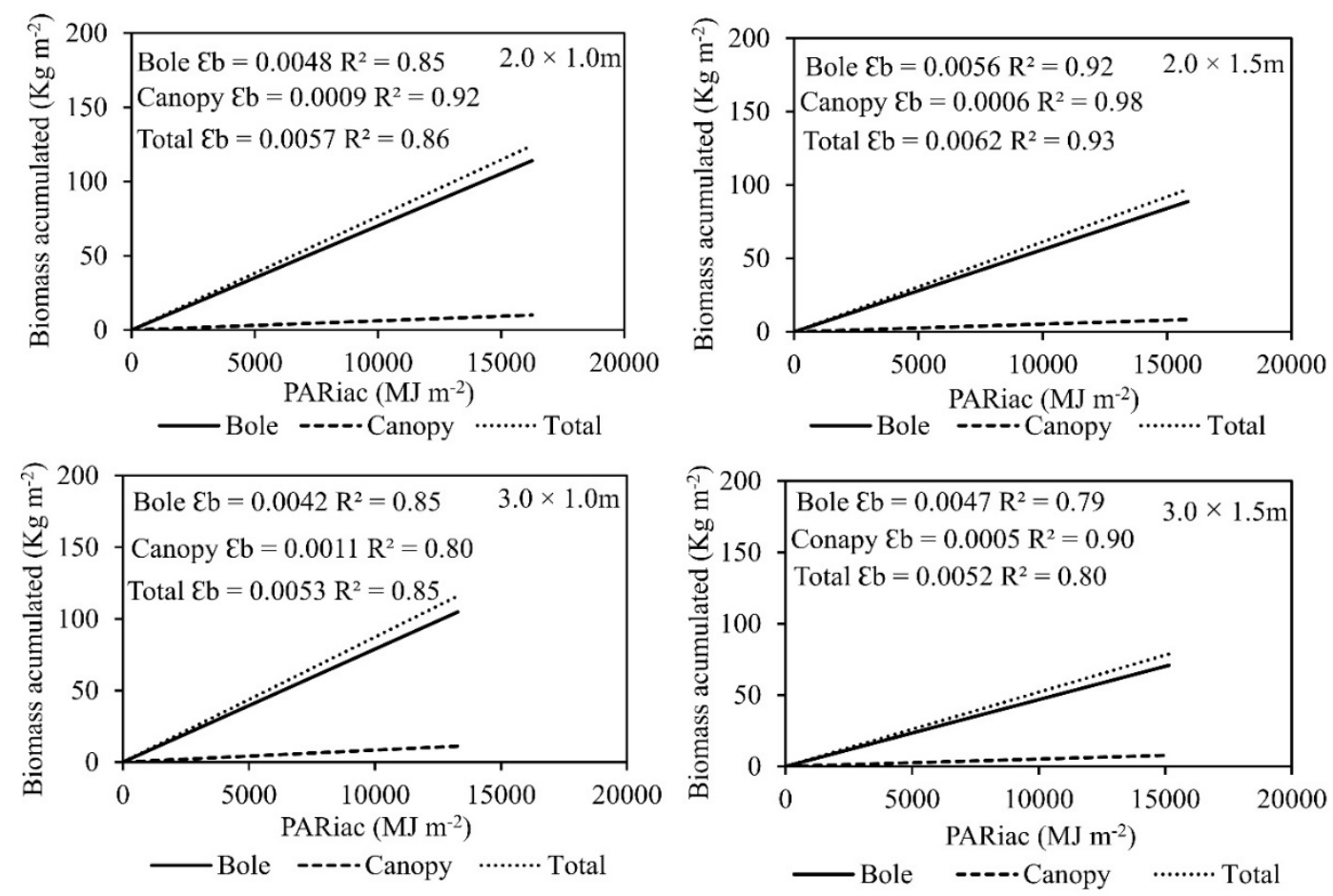

Figure 2- Radiation use efficiency for the bole, canopy, and total biomass obtained for each planting spacing of Eucalyptus grandis during the short-rotation cycle, where: $\varepsilon b=$ Conversion efficiency of intercepted photosynthetically active radiation into biomass, PARiac = photosynthetically active radiation intercepted accumulated.

Moreover, this study demonstrated that Eucalyptus trees grown under denser planting spacing, i.e., less than $2.0 \times 1.5 \mathrm{~m}$, showed a trend of reducing the RUE. This can be attributed to the increase in intra-interspecific competition for resources and the greater heterogeneity within the forest stand, where some plants were suppressed by others.

During the time that resources are available (i.e., canopy closure is not reached) all trees of a stand are equally efficient. However, when inter-tree competition starts, larger trees are able to acquire more resources, whereas smaller trees might already reach their resource compensation point, i.e., the minimum resource quantity needed to produce positive growth (Binkley, 2004; Fernández \& Gyenge, 2009). According to Campoe et al. (2013a), larger trees within a stand grow faster than smaller trees, not only because they intercept more light but also because they use that light more efficiently.

The general trend of increasing RUE with increasing tree size was consistent with results obtained in other studies (Campoe et al., 2013a). They reported that across a productivity gradient, on average, dominant trees (top 20\% in size) showed $37 \%$ greater RUE than suppressed trees (smallest 20\%). Moreover, the differences in RUE between dominant and non-dominant trees are consistent and become larger on more productive plots. This pattern was also observed by Campoe et al. (2013b) when assessing a Pinus taeda plantation in the USA. These results suggest that dominant trees will become even more dominant over suppressed trees on sites with higher resource availabilities.

In an intensive exploitation of forest energy plantations, at the stand level, higher RUE in more productive stands might result in a greater rate of photosynthesis per unit of absorbed photosynthetically active radiation, or from increased partitioning of carbohydrates to tree growth (Giardina et al., 2003; O'Grady et al., 2010; Campoe et al. 2012). Therefore, future 
studies should focus on understanding the impact of tree dominance and stand uniformity on $\mathrm{RUE}$, and consequently on forest biomass yield.

\section{Forest biomass yield and partitioning}

The biomass yield varied significantly for the different planting spacings (Figure 3A). The highest value of biomass yield $\left(961.4 \mathrm{Mg} \mathrm{ha}^{-1}\right.$ ) was obtained in the reduced planting spacing of $2.0 \times 1.0 \mathrm{~m}$, in the 9th year. Moreover, as the forest age increases, there is a trend of trees presenting similar values of biomass, regardless of the planting spacing. This study demonstrated that the individual relative biomass yield of trees is greater at the widest spacing levels $(3.0 \times 1.5 \mathrm{~m})$, potentially due to higher availability of soil and climate resources. However, when the authors varied the tree density from 1600 trees ha-1 at the $3.0 \times 1.5 \mathrm{~m}$ spacing to 3050 trees ha-1 at the $2.0 \times 1.0 \mathrm{~m}$ spacing level, the overall biomass yield of a unit area of land could be quite different compared to the average stand-alone tree size. Therefore, the number of trees per unit area becomes a relevant aspect that should be considered for the production of biomass for energy. In this study, it was possible to highlight that for the production of Eucalyptus, the optimal spacing of plants to produce highest forest biomass was $2.0 \times 1.0 \mathrm{~m}$.
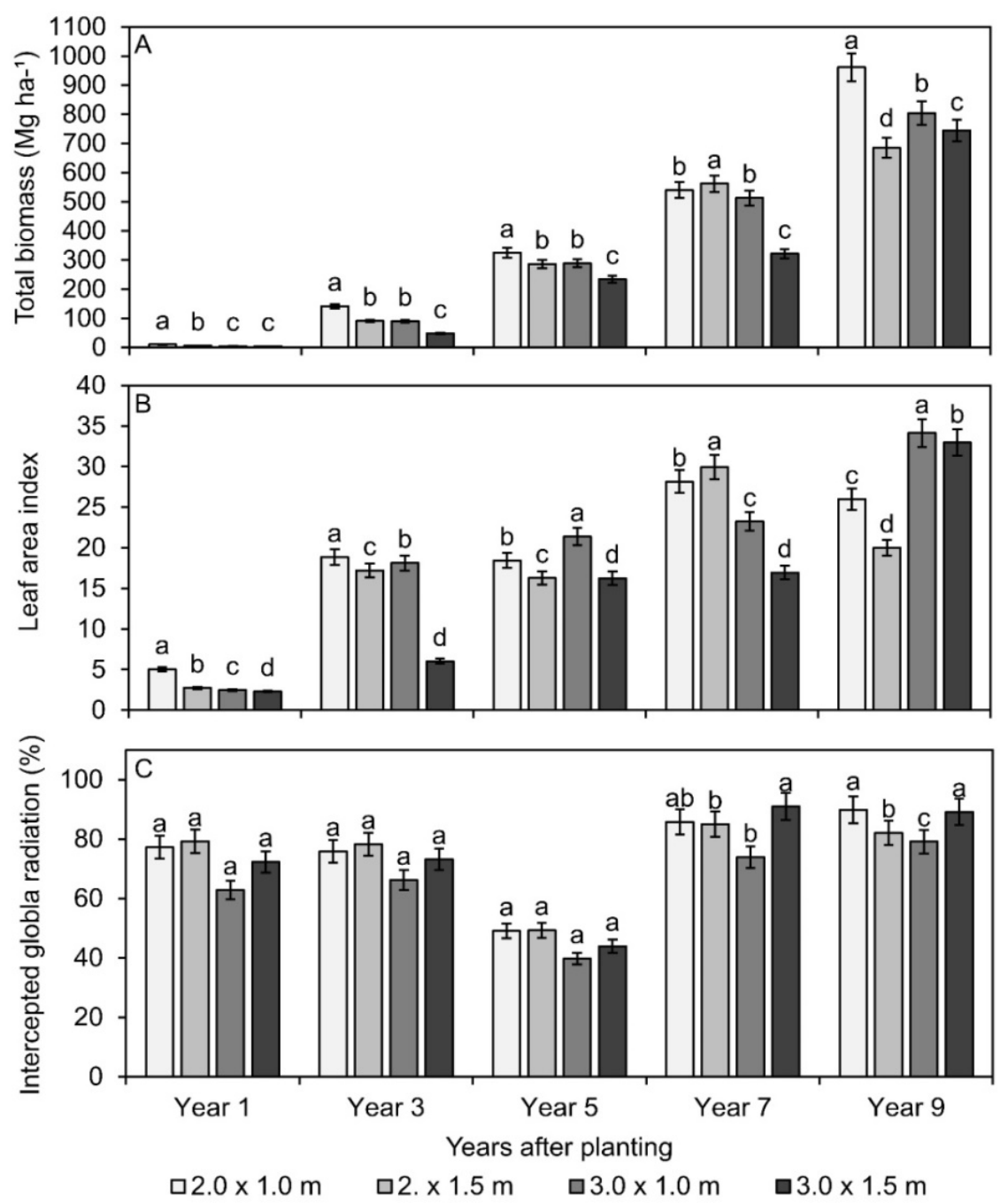

Figure 3- Biomass yield (A), leaf area index (B) and solar radiation interception (C) during the shortrotation cycle of Eucalyptus grandis grown under four planting spacings. Different small letters indicate significant differences $(p<0.05)$ by Tukey test among planting spacings in each assessment year. 
Significant differences were observed in the LAI for the different planting spacings and assessment years. Until the seventh year after planting, the $2.0 \times 1.0 \mathrm{~m}$ spacing presented one of the highest LAI. However, from the ninth year on, the highest LAI was found in the $3.0 \times 1.0$ m spacing (Figure 3B).

Similar values of intercepted solar radiation were found up to the fifth year across all spacings (Figure 3C). The lowest intercepted solar radiation was observed in the fifth year for all plant spacings, and may indicate a period of greater tree competition caused by abiotic factors. In all the years of evaluation, the trees cultivated in the spacing of $3.0 \times 1.0 \mathrm{~m}$ presented less interception of the solar radiation relative to other spacings. The highest intercepted solar radiation was $90.9 \%$, verified for the $3.0 \times 1.5 \mathrm{~m}$ spacing and in the 7 th year.

The largest biomass production of trees grown under the spacing $2.0 \times 1.0 \mathrm{~m}$ is explained by the larger number of plants per hectare. Thus, shorters pacing is recommended for shortrotation Eucalyptus plantations for biomass production, as they result in greater biomass accumulation per hectare. Eloy et al. (2015) evaluated forest species in short-rotation plantations for energy purposes and recommended short spacings for a higher biomass per area. The accumulated biomass found in the present study was higher than that found by Brito et al. (1983) for 10-year old Eucalyptus grandis (518.2 $\mathrm{Mg} \mathrm{ha}^{-1}$ ) and Eucalyptus pilularis $\left(500.8 \mathrm{Mg} \mathrm{ha}^{-1}\right)$ plants. The accumulated biomass difference can be explained by the genetic improvement that the species has been gaining over time.

Regarding the forest biomass increment during the evaluation years, we can observe that the highest mean annual increment values were obtained in $2.0 \times 1.0 \mathrm{~m}$ planting spacing with $106.8 \mathrm{Mg} \mathrm{ha}^{-1}$ until the 9th year (Figure 4). The same was observed for current annual increment, excluding the 9th year, where the highest value was obtained in $3.0 \times 1.5 \mathrm{~m}$ spacing (423.2 Mg ha-1). According to Oliveira et al. (2009), denser spacing tend to present larger increments when compared to less dense plantings. However, over time, competition for solar radiation and water tends to increase in denser spacing, reducing growth rates. This does not occur in the $3.0 \times 1.5 \mathrm{~m}$ spacing. Thus, the tendency over the years is for biomass to be equivalent in different spacings, even when there is a larger number of trees with denser spacing.
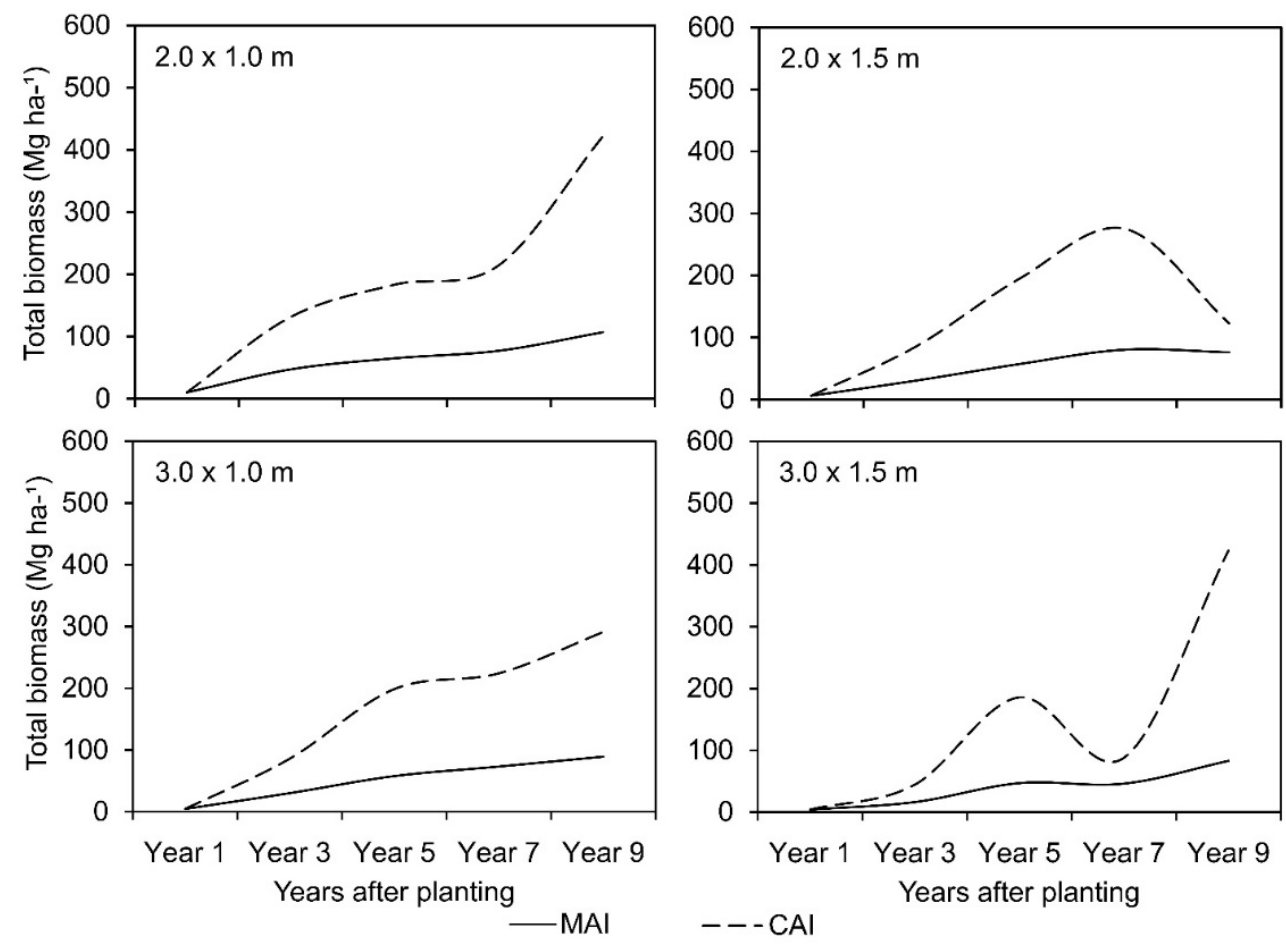

Figure 4- Current annual increment (CAl) and mean annual increment (MAl) of biomass during the short rotation cycle of Eucalyptus grandis cultivated in four planting spacings. 
In relation to the biomass partition in the different tree compartments, the canopy represented $71.6 \%$ and the trunk $28.4 \%$ of the total forest biomass produced in the first year, on average across the four plant spacings (Figure 5). However, these results were reversed in the ninth year, when the trunk represented $90 \%$, and the canopy represented $10 \%$ of the total biomass, also as averaged across the four planting spacings.
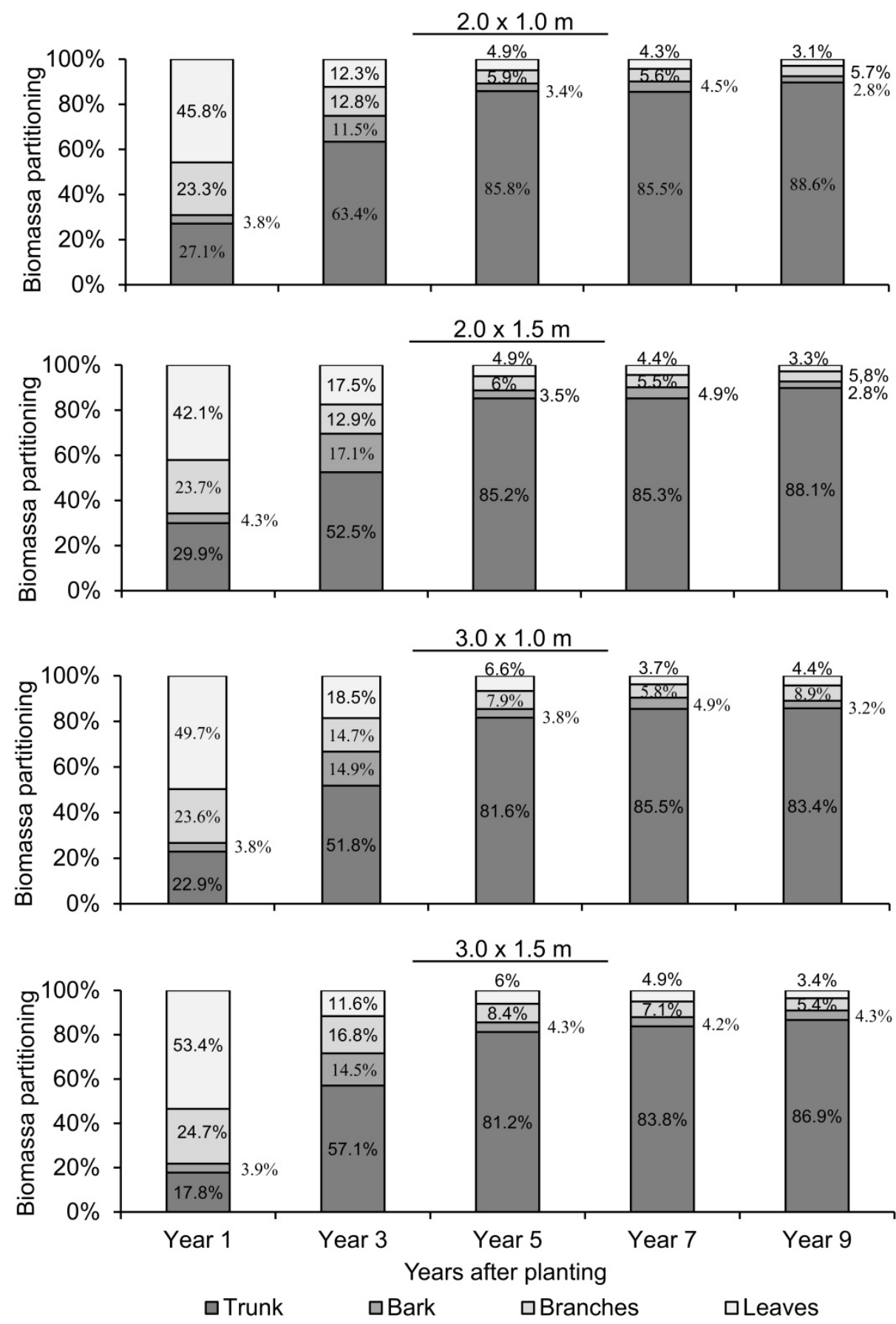

Figure 5- Biomass partitioning during the short-rotation cycle of Eucalyptus grandis grown under four planting spacings.

Overall, in the first year after planting, $24.4 \%, 4.0 \%, 23.8 \%$, and $47.8 \%$ of the biomass was represented by the trunk, bark, branch, and leaf components, respectively. These components represented $86.8 \%, 3.3 \%, 6.45 \%$, and $3.6 \%$ of the biomass, respectively, in the ninth year. The 
biomass percentage of the trunk component varied only $1.9 \%$ from the smallest $(2.0 \times 1.0 \mathrm{~m})$ to the largest $(3.0 \times 1.5 \mathrm{~m})$ spacing in the ninth year after planting.

The proportion of biomass accumulated in the different components was not influenced by the spacings (Figure 4). The leaf component presented higher biomass in all spacings in the first year, and the trunk component presented higher biomass in all spacings from the third year on. According to Gonçalves \& Passos (2000) and Schwerz et al. (2019), trees have a rapid increase in nutrient accumulation, and growth in the first years, mainly with allocation of photo-assimilates to the canopy. After the canopy growth and closure, when the plant has the highest LAl, the allocation of the nutrients is directed to the trunk.

In general, the percentage of biomass of the trunk component increases with increasing age of the trees (Oliveira Neto et al., 2010), while the percentage of the other components decreases. Sanquetta et al. (2014a) evaluated the biomass of Acacia mearnsii plantations of different ages and found variations in the biomass of each component with the age of the trees, with decreases in the leaf and branch components and increases in the trunk components, which represented $80 \%$ of the total biomass in the seven years after planting.

As there is a tendency for accumulation of biomass in the trunk with an increase in the age of the trees, Schumacher et al. (2011) recommends that the harvest be conducted from 6 years after planting. Harvesting any earlier to that is suggested to lead to reductions in yield of trunk.

The area of Eucalyptus plantations in Brazil is constantly growing, making the development of studies in the area of silviculture, ecology and management of this species even more relevant. The data generated in this study are valuable since it provides information for forest companies and forester producers regarding the optimal spacing of planting to be used for biomass production and energy generation.

\section{CONCLUSIONS}

The conversion efficiency of the photosynthetically active radiation intercepted in biomass was affected by the spacing of planting, and the highest conversion efficiency was $0.0062 \mathrm{~kg} \mathrm{MJ}^{-1}$ for the $2.0 \times 1.5 \mathrm{~m}$ spacing. In addition, Eucalyptus trees grown on the $2.0 \times 1.0$ $\mathrm{m}$ spacing showed the highest biomass yield with $961.4 \mathrm{Mg} \mathrm{ha}^{-1}$, demonstrating that the most efficient plants in the conversion of photosynthetically active radiation are not always the most productive. The hypothesis of this study was confirmed; forest managers can accelerate growth and increase the production of forest biomass by using the appropriate spacing for planting.

The results obtained in this study indicate that the optimal spacing of trees is smaller than the current pattern of $3.0 \times 1.5 \mathrm{~m}$. In this way, reduction of the planting spacing should be recommended for forest energy plantations, changing the current planting spacing pattern $(3.0 \times 1.5 \mathrm{~m})$ used by the majority of the forest producers. We emphasize that future studies should focus on understanding the impact of the use of high levels of fertilizers and forest stand uniformity on growth traits, solar radiation dynamics and consequently on forest biomass yield.

\section{ACKNOWLEDGMENTS}

The authors would like to thank the National Council for Scientific and Technological Development (CNPq-Brasil) and the Higher Education Personnel Improvement Coordination (CAPES-Brasil) for their financial support and scholarships at at the following levels: Scientific Initiation, Study and Productivity.

\section{REFERENCES}

Alvares, C. A., Stape, J. L., Sentelhas, P. C., de Moraes Gonçalves, J. L., \& Sparovek, G. (2013). Köppen's climate classification map for Brazil. Meteorologische Zeitschrift (Berlin), 22(6), 711-728.

http://dx.doi.org/10.1127/0941-2948/2013/0507. 
Assis, F. N., \& Mendez, M. E. G. (1989). Relação entre radiação fotossinteticamente ativa e radiação global. Pesquisa Agropecuária Brasileira, 24(7), 797-800.

Behling, A., Sanquetta, C. R., Dalla Corte, A. P., Caron, B., Simon, A. A., Behling, M., \& Schmidt, D. (2015). Conversion efficiency of photosynthetically active radiation intercepted in biomass in stands of black wattle in Brazil. Bosque (Valdivia), 36(1), 61-69. http://dx.doi.org/10.4067/S071792002015000100007.

Binkley, D. (2004). A hypothesis about the interaction of tree dominance and stand production through stand development. Forest Ecology and Management, 190(2-3), 265-271. http://dx.doi.org/10.1016/j.foreco.2003.10.018.

Binkley, D., Stape, J. L., Bauerle, W. L., \& Ryan, M. G. (2010). Explaining growth of individual trees: light interception and efficiency of light use by Eucalyptus at four sites in Brazil. Forest Ecology and Management, 259(9), 1704-1713. http://dx.doi.org/10.1016/j.foreco.2009.05.037.

Brito, J. O., Barrichelo, L. E. G., Seixas, F., Migliorini, A. J., \& Muramoto, M. C. (1983). Análise da produção de energética e de carvão vegetal de espécies de eucalipto. Instituto de Pesquisas e Estudos Florestais (IPEF), 23(23), 53-56.

Campoe, O. C., Stape, J. L., Albaugh, T. J., Lee Allen, H., Fox, T. R., Rubilar, R., \& Binkley, D. (2013b). Fertilization and irrigation effects on tree level above ground net primary production, light interception and light use efficiency in a loblolly pine plantation. Forest Ecology and Management, 288, 43-48. http://dx.doi.org/10.1016/j.foreco.2012.05.026.

Campoe, O. C., Stape, J. L., Laclau, J. P., Marsden, C., \& Nouvellon, Y. (2012). Stand-level patterns of carbon fluxes and partitioning in a Eucalyptus grandis plantation across a gradient of productivity, in São Paulo State, Brazil. Tree Physiology, 32(6), 696-706. PMid:22543478. http://dx.doi.org/10.1093/treephys/tps038.

Campoe, O. C., Stape, J. L., Nouvellon, Y., Laclau, J. P., Bauerle, W. L., Binkley, D., \& Le Maire, G. (2013a). Stem production, light absorption and light use efficiency between dominant and non-dominant trees of Eucalyptus grandis across a productivity gradient in Brazil. Forest Ecology and Management, 288, 14-20. http://dx.doi.org/10.1016/j.foreco.2012.07.035.

Caron, B. O., Souza, V. Q., Trevisan, R., Behling, A., Schmidt, D., Bamberg, R., \& Eloy, E. (2012). Eficiência de conversão da radiação fotossinteticamente ativa interceptada em fitomassa de mudas de eucalipto. Revista Árvore, 36(5), 833-842. http://dx.doi.org/10.1590/S0100-67622012000500005.

Eloy, E., Caron, B. O., Silva, D. A., Souza, V. Q., Trevisan, R., Behling, A., \& Elli, E. F. (2015). Produtividade energética de espécies florestais em plantios de curta rotação. Ciência Rural, 45(8), 1424-1431. http://dx.doi.org/10.1590/0103-8478cr20130177.

Fernández, M. E., \& Gyenge, J. (2009). Testing Binkley's hypothesis about the interaction of individual tree water use efficiency and growth efficiency with dominance patterns in open and close canopy stands. Forest Ecology and Management, 257(8), 1859-1865. http://dx.doi.org/10.1016/j.foreco.2009.02.012.

Forrester, D. I., Collopy, J. J., Beadle, C. L., \& Baker, T. G. (2013). Effect of thinning, pruning and nitrogen fertiliser application on light interception and light-use efficiency in a young Eucalyptus nitens plantation. Forest Ecology and Management, 288, 21-30. http://dx.doi.org/10.1016/j.foreco.2011.11.024.

Giardina, C. P., Ryan, M. G., Binkley, D., \& Fownes, J. H. (2003). Primary production and carbon allocation in relation to nutrient supply in a tropical experimental forest. Global Change Biology, 9(10), 14381450. http://dx.doi.org/10.1046/j.1365-2486.2003.00558.x.

Gonçalves, J. L. M., Alvares, C. A., Higa, A. R., Silva, L. D., Alfenas, A. C., Stahl, J., Ferraz, S. F. B., Lima, W. P., Brancalion, P. H. S., Hubner, A., Bouillet, J. P. D., Laclau, J. P., Nouvellon, Y., \& Epron, D. (2013). Integrating genetic and silvicultural strategies to minimize abiotic and biotic constraints in Brazilian eucalypt plantations. Forest Ecology and Management, 301, 6-27. https://doi.org/10.1016/j.foreco.2012.12.030.

Gonçalves, M. R., \& Passos, C. A. M. (2000). Crescimento de cinco espécies de eucalipto submetidas a déficit hídrico em dois níveis de fósforo. Ciência Florestal, 10(2), 145-161. http://dx.doi.org/10.5902/19805098488.

Landsberg, J. J., \& Hingston, F. J. (1996). Evaluating a simple radiation/dry matter conversion model using data from Eucalyptus g/obulus plantations in Western Australia. Tree Physiology, 16(10), 801-808. PMid:14871669. http://dx.doi.org/10.1093/treephys/16.10.801.

Le Maire, G., Nouvellon, Y., Christina, M., Ponzoni, F. J., Gonçalves, J. L. M., Bouillet, J. P., \& Laclau, J. P. (2013). Tree and stand light use efficiencies over a full rotation of single-and mixed-species 
Eucalyptus grandis and Acacia mangium plantations. Forest Ecology and Management, 288, 31-42. http://dx.doi.org/10.1016/j.foreco.2012.03.005.

Lopes, E. D., Laia, M. L., Santos, A. S., Soares, G. M., Pinto Leite, R. W., \& Martins, N. S. (2017). Influência do espaçamento de plantio na produção energética de clones de Corymbia e Eucalyptus. Floresta, 47(1), 95-104. http://dx.doi.org/10.5380/rf.v47i1.47141.

Monsi, M., \& Saeki, T. (1953). The light factor in plant communities and its significance for dry matter production. Japanese Journal of Botany, 14(1), 22-52.

Monteith, J. L. (1977). Climate and the efficiency of crop production in Britain. Philosophical Transactions of the Royal Society of London. Series B, Biological Sciences, 281(980), 277-294.

O'Grady, A. P., Eyles, A., Worledge, D., \& Battaglia, M. (2010). Seasonal patterns of foliage respiration in dominant and suppressed Eucalyptus globulus canopies. Tree Physiology, 30(8), 957-968. PMid:20601436. http://dx.doi.org/10.1093/treephys/tpq057.

Oliveira Neto, S. N., Reis, G. G., Reis, M. G. F., Leite, H. G., \& Neves, J. C. L. (2010). Crescimento e distribuição diamétrica de Eucalyptus camaldulensis em diferentes espaçamentos e níveis de adubação na região de Cerrado de Minas Gerais. Floresta, 40(4), 755-762.

Oliveira, T. K., Macedo, R. L. G., Venturin, N., \& Higashikawa, E. M. (2009). Desempenho silvicultural e produtivo de eucalipto sob diferentes arranjos espaciais em sistema agrossilvipastoril. Pesquisa Florestal Brasileira, 60, 1-9.

Pinkard, E. A., \& Neilsen, W. A. (2003). Crown and stand characteristics of Eucalyptus nitens in response to initial spacing: implications for thinning. Forest Ecology and Management, 172(2-3), 215-227. http://dx.doi.org/10.1016/S0378-1127(01)00803-9.

Pretzsch, H., \& Biber, P. (2016). Tree species mixing can increase maximum stand density. Canadian Journal of Forest Research, 46(10), 1179-1193. http://dx.doi.org/10.1139/cjfr-2015-0413.

Sanquetta, C. R. (2002). Métodos de determinação de biomassa florestal. As florestas e o carbono (pp. 119140). Curitiba: Ed. dos Autores.

Sanquetta, C. R., Behling, A., Corte, A. P. D., Simon, A., Pscheidt, H., Ruza, M. S., \& Mochiutti, S. (2014a). Estoques de biomassa e carbono em povoamentos de acácia negra em diferentes idades no Rio Grande do Sul. Scientia Forestalis, 42(103), 361-370.

Sanquetta, C. R., Behling, A., Corte, A. D., Cadori, G. C., Costa Junior, S., \& Macedo, J. P. (2014b). Eficiência de conversão da radiação fotossintética interceptada em Fitomassa de mudas de Eucalyptus dunii Maiden em função da densidade de plantas e do ambiente de cultivo. Scientia Forestalis, 42(104), 573-580.

Schumacher, M. V., Witschoreck, R., \& Calil, F. N. (2011). Biomassa em povoamentos de Eucalyptus spp. de pequenas propriedades rurais em Vera Cruz, RS. Ciência Florestal, 21(1), 17-22. http://dx.doi.org/10.5902/198050982743.

Schwerz, F., Caron, B. O., Elli, E. F., Eloy, E., Schmidt, D., Stolzle, J. R., Medeiros, S. L. P., Sgarbossa, J., \& Trevisan, R. (2017). The high density of plants increases the radiation use efficiency of photosynthetically active seedlings of Japanese grape ('Hovenia dulcis'). Australian Journal of Crop Science, 11(1), 50-54. http://dx.doi.org/10.21475/ajcs.2017.11.01.pne206.

Schwerz, F., Eloy, E., Elli, E. F., \& Caron, B. O. (2019). Reduced planting spacing increase radiation use efficiency and biomass for energy in black wattle plantations: towards sustainable production systems. Biomass and Bioenergy, 120, 229-239. http://dx.doi.org/10.1016/j.biombioe.2018.11.034.

Sereghetti, G. C., Lanças, K. P., Sartori, M. S., Rezende, M. A., \& Soler, R. R. (2015). Efeito do espaçamento no crescimento e na densidade básica da madeira de Eucalyptus urophylla $\times$ Eucalyptus grandis em florestas de ciclo curto. Energia na Agricultura, 30(3), 257-262. http://dx.doi.org/10.17224/EnergAgric.2015v30n3p257-262.

Silva, D. A., Muller, B. V., Kuiaski, E. C., Eloy, E., Behling, A., \& Colaço, C. M. (2015). Propriedades da madeira de Eucalyptus benthamii para produção de energia. Pesquisa Florestal Brasileira, 35(84), 481 485. http://dx.doi.org/10.4336/2015.pfb.35.84.677.

Stape, J. L., Binkley, D., \& Ryan, M. G. (2004). Eucalyptus production and the supply, use and efficiency of use of water, light and nitrogen across a geographic gradient in Brazil. Forest Ecology and Management, 193(1-2), 17-31. http://dx.doi.org/10.1016/j.foreco.2004.01.020.

Stape, J. L., Binkley, D., Ryan, M. G., Fonseca, S., Loos, R. A., Takahashi, E. N., Silva, C. R., Silva, S. R., Hakamada, R. E., Ferreira, J. M. A., Lima, A. M. N., Gava, J. L., Leite, F. P., Andrade, H. B., Alves, J. M., Silva, G. G. C., \& Azevedo, M. R. (2010). The Brazil Eucalyptus Potential Productivity Project: influence of water, nutrients and stand uniformity on wood production. Forest Ecology and Management 259(9), 1684-1694. http://dx.doi.org/10.1016/j.foreco.2010.01.012. 
Statistical Analysis System - SAS. (2003). Getting started with the SAS learning edition. Care, North Carolina: SAS Institute Inc.

Varlet-Grancher, C., Gosse, G., Chartier, M., Sinoquet, H., Bonhomme, R., \& Allirand, J. M. (1989). Mise au point: rayonnement solaire absorbé ou intercepté par um couvert vegetal. Agronomie, 9(5), 419-439. http://dx.doi.org/10.1051/agro:19890501.

Welfle, A. (2017). Balancing growing global bioenergy resource demands - Brazil's biomass potential and the availability of resources for trade. Biomass and Bioenergy, 105, 83-95. http://dx.doi.org/10.1016/j.biombioe.2017.06.011.

Author's contributions: CN: Data curation, formal analysis, investigation, writing - original draft; FS: Formal analysis, methodology, writing - review \& editing; DDN: Writing - review \& editing; EE: Conceptualization, methodology, writing - review \& editing; EFE: Methodology, writing - review \& editing; JS: Methodology, writing review \& editing; LBT: Methodology, writing - review \& editing; DS: Writing - review \& editing; BOC: Conceptualization, project administration, resources, supervision, writing - review \& editing. 